\title{
Beata Przyborowska, „Pedagogika innowacyjności. Między teorią i praktyką", Wydawnictwo Naukowe UMK, Toruń 2013
}

Książka Beaty Przyborowskiej „Pedagogika innowacyjności. Między teorią i praktyką" składa się z 7 rozdziałów, ( poprzedzonych wstępem „Od Autorki” i „Wprowadzeniem”), bibliografii obejmującej 14 stron.

We wprowadzeniu Autorka uzasadnia potrzebę podjęcia problematyki innowacyjności w edukacji stwierdzając, że obecną fazę rozwoju kulturowego można nazwać epoką hiperinnowacyjną, w której innowacyjność stała się wartością samą w sobie, ale także realizowana jest w coraz liczniejszych, coraz bardziej innowacyjnych formach. Jej zasięg $\mathrm{i}$ wpływ jest widoczny niemal we wszystkich sferach praktyki społecznej".

Rozdział 1 - „Podstawy wiedzy o innowacjach w edukacji” - obejmuje uwagi o rozwoju teorii innowacji, studiami nad innowacjami w edukacji, definiuje podstawowe kategorie pojęciowe współczesnych teorii innowacji oraz innowacyjność jako kategorię, przedstawia zarys metodologii badań nad innowacjami oraz pokazuje redukcjonizm teorii innowacji w edukacji.

Autorka zwraca uwagę, że problematyka innowacyjności była przede wszystkim przedmiotem badań jedynie historii kultury oraz nauk ekonomicznych, które zostały przymuszone do zajęcia się tą problematyką w związku z konkurencją na rynku pracy i w handlu. Dlatego też innowacje najczęściej były kojarzone ze sferą techniczno-technologiczną. Dla pełnego rozwoju cywilizacyjnego, niezbędne jednak są też działania innowacyjne w sferze społecznej i edukacyjnej (s.29-30). Wiedza przeciętnego pedagoga o istocie zmian do niedawna była kształtowana „przeszłościowo”, głównie z perspektywy historii i filozofii wychowania. Autorka zauważa, że w czasach obecnych istnieje zapotrzebowanie na nową koncepcje zmian edukacyjnych. W tym kontekście, uwypukla myślenie R. Schulza, który twierdzi, że koncepcja zmiany powinna zawierać przynajmniej trzy elementy: zdolność 
systemu do inicjowania i recepcji zmian, tworzeniu programów reformatorskich wspartych na naukowych podstawach, zdolność do przekraczania granic techniczno-instrumentalnych.

Jednak, zdaniem Autorki, pomimo że już od jakiegoś czasu podejmowana jest problematyka innowacji w edukacji, to nie wypracowano dotychczas „całościowego jej ujęcia w kontekście zarówno rozwoju jednostek, grup, organizacji tworzących i przyswajających innowacje, jak i procesów oraz zachowań towarzyszących tym zjawiskom itp. Brakuje nam również szerszego, kulturowego i społecznego kontekstu rozpatrywania innowacji. Innowację i innowacyjność trudno analizować w oderwaniu od warunków zewnętrznych, w jakich funkcjonuje jednostka i warunki zewnętrzne, nie sposób analizować, nie biorąc pod uwagę wnętrza jednostki i jego wpływu na zachowania jednostek i grup społecznych (kultury)" (s. 65) Zacytowana myśl stanowi „zasadę nawigacyjną" w dalszych rozważaniach o innowacyjności w edukacji.

W rozdziale 2 - „Nowe ujęcie problematyki innowacyjności” - Autorka definiuje zapotrzebowanie na nową koncepcję innowacji. Powinna ona (koncepcja) mieć „charakter bardziej uniwersalny i kompletny” oraz powinna łączyć „tradycję z jej alternatywnymi rozwiązaniami”, pokazywać łączność teorii i praktyki, przez co mogłaby stanowić podstawę i wspólną płaszczyznę dla „twórczej wymiany poglądów zarówno w obszarze teorii, jak i praktyki edukacji konwencjonalnej i alternatywnej" (s. 71). W dalszej części zaprezentowane zostały wybrane modele całościowego podejścia do badań na innowacjami. Wyeksponowany został w szczególności model czterech ćwiartek Kena Wilbera, jako mapa pozwalająca orientować się w złożonej rzeczywistości, chroniąca przed ryzykiem redukcjonizmu. „Kwadranty pojawiają się jednocześnie jako cztery podstawowe aspekty jednostkowego bycia w świecie: wewnętrzny i zewnętrzny oraz indywidualny i kolektywny wymiar. Te cztery wymiary dotyczą każdej sytuacji, każdego zdarzenia, w którym jednostka uczestniczy. Mówiąc inaczej cztery kwadranty są podstawowymi wymiarami każdego zdarzenia lub sytuacji. Ponadto jednostka może z perspektywy czterech kwadrantów patrzeć na każdy aspekt rzeczywistości: inną osobę, przedmiot, organizację, ekosystem. Wtedy mówimy nie o kwadrantach, a o kwadrywiach. Kwadranty będą wymiarami mojego funkcjonowania, kwadrywia będą perspektywami, z których oceniam różne fenomeny rzeczywistości" (s. 81).W kolejnych podrozdziałach Autorka rozwija opis koncepcji Wilbera pokazując też różnorakie jej zastosowania, proponując integralny pluralizm metodologiczny w badaniach innowacji. Te rozważania są szczególnie cenne i ważne w sytuacji, kiedy pluralizm metodologiczny jako interdyscyplinarrna czy nawet transdyscyplinarna koncepcja oglądu rzeczy- 
wistości, cały czas wzbudza podejrzliwość w środowiskach badaczy uznających rzetelność jedynie redukcjonistycznych perspektyw badawczych.

W następnych czterech rozdziałach: (3) „Perspektywa intencjonalna subiektywna”, (4) „Perspektywa behawioralna - obiektywna”, (5) „Perspektywa kulturowa - intersubiektywna”, (6) „Perspektywa społeczna - interobiektywna", zawarte zostały najważniejsze treści tej książki. Omawiana jest w nich problematyka innowacyjności zgodnie z opisaną wcześniej czteroćwiartkową metodą oglądu.

W rozdziale 3 zawarta jest charakterystyka człowieka jako jednocześnie podmiotu i obiektu zmian. Kluczową kategorią definiowaną w tym rozdziale na różne sposoby jest osobowość (innowacyjna). Autorka, świadoma skłonności intelektu do redukcjonistycznego rozumienia rzeczywistości, w metanarracji nieustannie przypomina - czyni to zresztą w całej pracy - że patrząc na fragment trzeba go zawsze umiejscawiać w całościowym kontekście. Przykładem jest zakończenie rozdziału 3: „Jednostka i jej świadomość subiektywna nie istnieją $\mathrm{w}$ próżni, jest ona nierozerwalnie związana $\mathrm{z}$ istniejącym organizmem i mózgiem (kwadrant górny prawy), z naturą, systemami społecznymi (kwadrant dolny prawy), jak również z kręgiem kulturowym, wspólnym dla niego systemem wartości i światopoglądem (kwadrant dolny lewy)".

W rozdziale 4 opisywane są zachowania, czynności i praktyki innowacyjne, ich istota i ewolucja. W drugiej części tego rozdziału charakteryzowana i klasyfikowana aktywność twórcza nauczyciela. Jak wykazuje to Autorka w tabeli (s. 173), praktyki innowacyjne mają umocowanie w doświadczeniu wewnętrznym (odczuciach, refleksji), w ocenie rezultatów aktywności, w zmianach kultury i sytemu edukacji.

W rozdziale 5 przedstawione jest znaczenie kultury jako środowiska intersubiektywnego. Omawiane są takie zagadnienia jak: kulturowe uwarunkowania innowacyjności, kultura jako kontekst procesów innowacyjnych, zależność pomiędzy kulturą edukacji a innowacjami, ale też kontrkultury innowacyjności. Zwieńczeniem, jak w każdym z czterech wyróżnionych powyżej rozdziałów, jest integralne czteroćwiartkowe ujęcie kultury.

W rozdziale 6 podejmowana jest problematyka otoczenia szkoły jako kontekstu dla edukacji. Autorka wyróżnia otoczenie ogólne szkoły, czyli środowisko szeroko pojętego społeczeństwa (wymiar społeczny, kulturowy, prawny, ekonomiczny, polityczny itd.) oraz otoczenie systemowe wiążące się z usytuowaniem organizacji edukacyjnej, ze względu na typ zaspokajanych i tworzonych potrzeb edukacyjnych. Omawia teoretyczne aspekty struktur i systemów innowacyjnych, porusza też problematyka praktycznych uwarunkowań innowacyjności w edukacji. Jeden z podrozdziałów poświęcony 
jest barierom innowacyjności w praktyce edukacyjnej. Ten rozdział również podsumowuje próba integralnego włączenia otoczenia szkoły w całość innowacyjności edukacyjnej.

Rozdział 7, ostatni, zaczyna się od konstatacji, że pedagogika sama w sobie jest innowacyjna. Następnie Autorka porusza wątek pedagogii jako praktyk edukacyjnych, w tym praktyk innowacyjnych. Ostatni podrozdział „Status pedagogiki innowacyjności" jest próbą określenia, czym jest pedagogika innowacyjności - Autorka proponuje, aby tą kategorią (subdyscypliną pedagogiki) objąć „praktyczne i poznawcze, wielowymiarowe i wieloparadygmatyczne podejście do działalności innowacyjnej w edukacji" (s. 281). Jednocześnie zauważa konieczność objęcia działaniami badawczymi wewnętrznych - osobistych i zbiorowych - uwarunkowań innowacyjności w edukacji.

Książka Beaty Przyborowskiej „Pedagogika innowacyjności” podejmuje problematykę innowacyjności w edukacji w sposób innowacyjny zgodnie z tym, co Autorka napisała we wstępnej części pracy: badanie innowacyjności wymaga innowacyjnych perspektyw metodologicznych. W tym celu zastosowała model czterech kwadrantów K. Wilbera - swoistą mapę orientującą rzeczywistość i na tej mapie umieściła różne podejścia do problematyki innowacyjności. W ten sposób pokazała, jak można korelować dane z zakresu ekonomii i psychologii, nauk o zarządzaniu i nauk o kulturze, pedagogiki i antropologii itd. Książka B. Przyborowskiej stanowi bardzo udaną próbę posłużenia się nadzwyczaj prostym narzędziem, w badaniu nadzwyczaj złożonego fenomenu, jakim jest innowacyjność. $W$ ten sposób praca ta, poza posiadaniem wysokiej wartości erudycyjnej, jest nowatorska pod względem metodologicznym. Efekt, jaki został uzyskany dzięki zastosowaniu modelu K. Wilbera, to $z$ jednej strony obniżenie poziomu entropii w zakresie wiedzy o innowacyjności w edukacji, a z drugiej strony otwarcie na nowe problemy.

Jeśli pedagogika ma uchodzić za naukę interdyscyplinarną, to musi posługiwać się narzędziami służącymi integrowaniu wiedzy, bo interdyscyplinarność nie polega na zbieractwie wiedzy z różnych dyscyplin nauki i upychaniu jej do szuflad typologii. Interdyscyplinarność polega na jednoczesnym widzeniu całości, specyfiki fragmentów tej całości i relacji między tymi fragmentami - w tę optykę wpisuje się „Pedagogika innowacyjności”. W swoich poszukiwaniach badawczych B. Przyborowska jest kontynuatorką myśli swojego nauczyciela R. Schulza, jednak kontynuując, rozwija i przekracza dokonania nauczyciela, co świadczy, zarówno o wysokich kompetencjach ucznia, jak i nauczyciela. 